\title{
HOW DO FACULTY CONCEPTIONS ON READING, WRITING AND THEIR ROLE IN THE TEACHING OF ACADEMIC LITERACIES INFLUENCE THEIR INCLUSIVE ATTITUDE
}

\author{
Laura Colombo* \\ Universidad de Buenos Aires \\ Buenos Aires, AR \\ Mónica Prior ${ }^{* *}$ \\ Centro Latinoamericano de Economía Humana \\ Montevideo, UY
}

\begin{abstract}
This study explored faculty conceptions about reading and writing, the student body, reasons for student lowperformance as well as their declared teaching practices aimed at helping students to better understand readings and write academic texts. The objective was to understand what type of professors' conceptions contributed with a more inclusive attitude towards first-year students. Content analysis from data gathered from in-depth interviews indicates that professors who acknowledged the complexity of the reading and writing processes tend to be more inclusive and to use reading and writing to teach and not just to evaluate. Those who taught writing courses tended to consider writing as a general skill, transferable to other contexts and spheres of knowledge. Less-inclusive teachers, explaining why they did not offer guidance or proposed remedial solutions, claimed that students should already have mastered academic reading and writing when entering the university and that teaching these skills implied being overprotective and not allowing them to mature.
\end{abstract}

Keywords: University Teaching; Academic Literacies; First-year Students; Inclusive Attitudes

\section{Introduction}

A common complaint heard in Latin American colleges is that students do not understand what they read and they cannot write properly (Carlino, 2005; Estienne \& Carlino, 2004). Along the same lines, in the Uruguayan ${ }^{1}$ higher education system there is a widespread concern about the difficulties that first-year students face when asked to read and produce academic texts: they cannot understand written prompts or identify the main ideas in readings, they copy and paste - plagiarize - in their written work and they barely can author their own papers; that is, they reproduce but do not learn what is supposedly taught. Moreover, entrance examinations do nothing but confirm that new students do not have the competencies expected at college (Altmark, Castrillejo, Debera, \& Nalbarte, 2006).

Additionally, after the first semesters many students withdraw or fall behind. Many of them leave their course of study feeling frustrated and believing that they are not good enough for college. This earlyattrition phenomena, then, reinforces the idea that higher education is only for the strongest: those who came with a "fit" cultural background or those who persisted at the expense of testing their self-esteem when facing failure and frustration. As Boado (2005) claims,

* A PhD in Language, Literacy and Culture and a Master in Intercultural Communication, Lauraq Colombo is a Professor at CONICET, at Buenos Aires University. Her email address is violeta.colombo@gmail.com

** A Master in Academic Pedagogy, Mónica Prior is a Professor at the Latin American Center of Human Economy. Her email address is moniprior@gmail.com 
causes for student attrition and degree completion behavior are associated not only with non-institutional but also with institutional factors. Therefore, colleges can coordinate efforts aimed at improving student retention and graduation.

In this scenario, university teaching quality becomes an important factor to reverse exclusion. In Uruguay, starting in the 1970s, rising enrollment rates have led to a change in the student body, and institutions host students coming from diverse social, economic and cultural origins and with widely varying interests and needs (Boado, 2005). Despite this change, teaching practices seem to be the same: selective and addressed to those who already count with learning tools (Behares, 2011; Biggs, 2005; Imbernón, 2000). Nevertheless, quality education requires teachers with a reflective attitude, capable of monitoring student learning outcomes in order to accommodate their teaching to the needs of students (Biggs, 2005).

As was mentioned before, reading and writing play a vital role in the academic life of college students because they can serve as powerful learning tools (Bereiter \& Scardamalia, 1987; Langer \& Applebee, 1987) and means to appropriate ways of thinking and doing in the disciplines (Carlino, 2005; Carter, Ferzli \& Wiebe, 2007; Koustouli, 2005) as well as promote student participation in disciplinary communities (Carter, 2007; Ketter \& Hunter, 2003). Now, whose responsibility is it to teach academic reading and writing?

Since the 1980s, metaphors related to immigration have been used to represent the process new students have to go through, such as students being "strangers in strange lands" (McCarthy, 1987) when entering college and having to deal with new uses of reading and writing. The student-as-an-immigrant metaphor was quite widespread in the U.S. context and some authors have even questioned its use (for example, Sutherland, 2010). Nevertheless, conceptualizing students as immigrants can help us better understand the challenges they face when entering higher education: they have to assimilate new ways of being with codes, implicit rules and values that are new to them. Institutions should take on this responsibility and, for example, professors could help newcomers to understand these new ways of being and doing by becoming mediators of texts cultures (Carlino, 2005; Dysthe, 2002).

With regard to teaching these new ways of reading and writing, two postures can be identified. On the one hand, some advocate that this task should be tackled by language specialists, specifically in courses designed to teach to read and write academic texts in general. On the other hand, the WAC (Writing Across the Curriculum) and the WID (Writing in the Disciplines) movements propose that professors in each discipline should also take responsibility in the teaching of these practices in a situated manner, in the here and now of every subject. In Uruguay, most institutions seem to support the first posture since several higher education institutions have first-year reading and writing courses taught by language specialists with a preparatory aim and, in some cases, curricular spaces devoted to support written works required to obtain a university degree such as thesis (Prior, 2014). Thus, the idea that reading and writing practices specific to each discipline can be taught only by those who enact them (disciplinespecific professors) does not seem to be present in Latin America, excepting a few cases (Carlino, 2013).

Despite these efforts, the aforementioned complaint that students "can't write" and "don't understand what they read" (Carlino, 2005, p. 21) keeps on being heard and the problem seems to belong to the students or to those who taught them before they came to the university. This research, then, explores Uruguayan professors' ideas about reading and writing, the student body, reasons for student low-performance and declared pedagogical actions aimed at helping students to better understand readings and to write academic texts. In sum, the objective is to understand what type of professors' conceptions contribute with a more inclusive attitude towards these students who are immigrants in different academic cultures.

Professors' conceptions and beliefs on teaching and learning influence their teaching practices but most of the times these remain implicit (Putnam \& Borko, 2000). Therefore, to improve ways of teaching, it is necessary to unveil them as to avoid a clash between educators' discourses and their pedagogical actions (Porlan \& Rivero, 1998). Examining what professors 
think and know about reading and writing pedagogies not only can serve to broaden our understanding of current teaching practices in Latin American countries but also constitute the basis for further pedagogical initiatives oriented towards a situated teaching of academic literacies. Given the importance that academic literacies have in undergraduate education, we hope to contribute by providing useful categories to further analyze the impact of professors' ideas on the way they teach and promote inclusive pedagogical actions. This can constitute a first step to address the problem of dropout rates and thus mitigate the amount of frustration that students have to deal with when feeling that they do not have the tools to fulfill their academic expectations.

\section{The study}

The purpose of the study was to explore professors' conceptions about academic reading and writing, the student body, and reasons for student low-performance. We also wanted to explore professors' ideas about the roles faculty and the institution should assume in the teaching of academic literacies to first-year students and what they declared to do about it in their own classrooms. This would help to determine different levels of academic inclusion and its relationship with ideas about learning academic reading and writing.

Research was conducted in a small private university in Uruguay comprised of three academic departments ${ }^{2}$ : Cultural Management, Law, and Medicine. Each academic department offers one undergraduate degree. The Department of Cultural Management is located in Montevideo, the capital of the country, and the Departments of Law and Medicine are located 140 kilometers to the East in the city of Maldonado, the second most populated in the country. This is a rather young institution given that none of the undergraduate degrees have been offered for more than a decade. In addition, classes are usually small, with an average number of 25 students per course. Introductory disciplinary and writing courses are offered independently by each department and they are taught in Spanish.
Introductory-course professors from all departments constituted the sampling frame. The sampling procedure was as follows: a self-administered survey and a letter asking for a face-to-face interview, both written in Spanish, were delivered to all faculty members who taught first-year courses in each department. Five professors were selected from all those who answered the survey (response rate of 25\%) trying to reach a variety of profiles: a) Juan, taught an introductory course on Public Health for the Department of Medicine; b) María, taught a first-year writing course for the Department of Law; c) Pedro taught an introductory Political Sciences course for the Department of Law; d) Ana taught an introductory course on Technology and Culture for the Department of Cultural Management; and e) Elena taught a firstyear writing course for the Department of Cultural Management.

Participants were interviewed in Spanish on the following topics: perceptions about first year students, students' issues with reading and writing, reasons for reading and writing problems, faculty and institutional strategies to face those problems, types of readings assigned to students, purposes and activities related to course-readings and writing activities, ideas about how students learn and the role reading and writing play in the learning process. Most of the questions were open and the order was modified during the interviews (Krathwohl, 1998). Additionally, probes were used to clarify and increase information (Lofland, Snow, Anderson, \& Lofland, 2006).

After the oral recordings were transcribed, content analysis (Bardin, 1986) was conducted combining inductive and deductive processes and using categorizing and contextualizing strategies (Maxwell \& Miller, 2008). Therefore, the coding was developed through an iterative process of examining transcripts, considering coding labels and categories, and examining more transcripts. As a result of this process, interviewees' answers were categorized in three dimensions: conceptions about academic reading, conceptions about academic writing, and conceptions about professors' roles on the teaching of academic literacies to first year students ${ }^{3}$ (see Table 1). 
118 Laura Colombo and Mónica Prior, How do faculty conceptions on reading, writing and...

Table 1. Data analysis dimensions and categories

\begin{tabular}{lll}
\hline Dimensions & Categories & Description \\
\hline $\begin{array}{l}\text { Conceptions } \\
\text { about reading }\end{array}$ & As information transfer & $\begin{array}{l}\text { Understanding is a direct result of decoding and lexical } \\
\text { knowledge (Cooper, 1990; Cairney, 1992). General skill } \\
\text { that once learned can be transferred to different contexts. } \\
\text { As an interactive process }\end{array}$ \\
& $\begin{array}{l}\text { Constructive process in which readers' knowledge } \\
\text { interacts with textual information. Reading } \\
\text { comprehension depends on: the reader's knowledge } \\
\text { about the topic, their reading purpose and the cognitive } \\
\text { and metacognitive reading strategies that they apply } \\
\text { (Goodman, 1986; Beck, 1996; Palincsar \& Brown, 1997; } \\
\text { Carlino, 2009). }\end{array}$ \\
\hline
\end{tabular}

Conceptions
about writing

As a complex decision making process Dependent on variables such as topic, audience, context,

Knowledge of the written code, lexical items, grammar, and orthography are enough to produce any kind of text. General and transferable skill. genre. It is recursive and has epistemic value (Flower \& Hayes, 1996; Bereiter \& Scardamalia, 1987).

\section{Professors' roles in the teaching of academic literacies}

Not responsible for reading and writing instruction

Remedial perspective

Responsible for reading and writing instruction as disciplinary contents
Academic reading and writing should have been learned in previous levels.

Higher level institutions should provide students with resources to "remediate" reading and writing deficits such as writing workshops, courses.

Disciplinary reading and writing should be taught. They acknowledge students' difficulties and they take responsibility by giving feedback and guiding students.

\section{Teaching profiles related to academic inclusion}

The three dimensions presented in Table 1 allowed us to distinguish three teaching profiles related to different levels of academic inclusion. This distinction was based on what interviewees said they thought and did regarding academic literacies teaching and the skills and knowledge needed to do so. Accordingly, professors with a high level of academic inclusion are aware of the level of complexity and the epistemic power that academic reading and writing practices entail. In addition, they acknowledge that learning these practices can represent a challenge and thus give feedback and guidance to students. Professors with a medium level of academic inclusion conceptualize reading and writing as complex processes but do not seize their epistemic potential. They notice that students need help but only offer remedial actions. Professors with a low level of academic inclusion do not perceive the complexity of these processes or their epistemic potential and do not help students, since they consider they should already master reading and writing practices. Table 2 presents characteristics that were defined for each level. 
Table 2: Characterization of the academic inclusion

levels

\begin{tabular}{|c|c|c|c|}
\hline & $\begin{array}{l}\text { High level of academic } \\
\text { inclusion }\end{array}$ & $\begin{array}{l}\text { Medium level of academic } \\
\text { inclusion }\end{array}$ & $\begin{array}{l}\text { Low level of academic } \\
\text { inclusion }\end{array}$ \\
\hline $\begin{array}{l}\text { Conceptualizations } \\
\text { about reading }\end{array}$ & $\begin{array}{l}\text { The interviewees understand } \\
\text { that readers should connect } \\
\text { textual information with } \\
\text { previous knowledge. } \\
\text { They assume that previous } \\
\text { knowledge is needed } \\
\text { to understand implicit } \\
\text { information provided by the } \\
\text { text. } \\
\text { They perceive that different } \\
\text { types of texts require different } \\
\text { types of reading strategies. } \\
\text { They realize that context } \\
\text { influences comprehension } \\
\text { They conceive that readers } \\
\text { execute complex cognitive } \\
\text { operations. }\end{array}$ & $\begin{array}{l}\text { The interviewees have many } \\
\text { or all of the characteristics of } \\
\text { the High level of academic } \\
\text { inclusion. }\end{array}$ & $\begin{array}{l}\text { The interviewees } \\
\text { attribute students' } \\
\text { reading difficulties to } \\
\text { decoding problems or } \\
\text { lack of vocabulary. } \\
\text { They consider that } \\
\text { good decoding and } \\
\text { attentive reading ensure } \\
\text { comprehension without } \\
\text { regard to the content of } \\
\text { the text. }\end{array}$ \\
\hline $\begin{array}{l}\text { Conceptualizations } \\
\text { about writing }\end{array}$ & $\begin{array}{l}\text { They conceptualize writing } \\
\text { as a complex process that } \\
\text { needs time, a purpose and an } \\
\text { audience. } \\
\text { They introduce writing tasks } \\
\text { with a potential epistemic value } \\
\text { in their courses. } \\
\text { They assume that specific } \\
\text { reading and writing practices } \\
\text { have to be learned at the } \\
\text { university. }\end{array}$ & $\begin{array}{l}\text { They have many or all of the } \\
\text { characteristics of the High } \\
\text { level of academic inclusion. }\end{array}$ & $\begin{array}{l}\text { They attribute writing } \\
\text { problems to micro level } \\
\text { aspects of the text such } \\
\text { as orthography, syntax, } \\
\text { and lexis. } \\
\text { When giving writing } \\
\text { tasks, they do not offer a } \\
\text { writing purpose, enough } \\
\text { guidance or time to } \\
\text { students. } \\
\text { They consider writing } \\
\text { as a general skill, } \\
\text { independent of the } \\
\text { content and that must } \\
\text { be learned in previous } \\
\text { educational levels. }\end{array}$ \\
\hline $\begin{array}{l}\text { Understanding } \\
\text { of their role } \\
\text { and } \\
\text { declared } \\
\text { teaching practices }\end{array}$ & $\begin{array}{l}\text { They consider that they have to } \\
\text { teach more than disciplinary } \\
\text { contents. } \\
\text { They propose reading and } \\
\text { writing tasks that prompt deep } \\
\text { learning. } \\
\text { They conceive new students as } \\
\text { immigrants in a new culture } \\
\text { that includes discursive } \\
\text { practices (Carlino, 2003). } \\
\text { They adjust their help based on } \\
\text { the challenges faced by students } \\
\text { (Coll, 2001). }\end{array}$ & $\begin{array}{l}\text { They have some characteristics } \\
\text { of the High level of academic } \\
\text { inclusion. } \\
\text { They consider that previous } \\
\text { educational experiences did } \\
\text { not prepare students well. } \\
\text { They propose to create } \\
\text { institutional initiatives to } \\
\text { compensate for students' } \\
\text { deficits. }\end{array}$ & $\begin{array}{l}\text { They consider students } \\
\text { immature and lacking } \\
\text { a "higher education" } \\
\text { attitude. } \\
\text { They think that students } \\
\text { should be helped. } \\
\text { They believe deficits are } \\
\text { irreversible: what has } \\
\text { not been learnt before, } \\
\text { cannot be learned now. }\end{array}$ \\
\hline
\end{tabular}


The different academic inclusion levels can be considered supra-categories that emerged from the relationships between the categories of the three analyzed dimensions. Given that our research was oriented by a theoretical problem, content analysis allowed us to generate a new instrument (Table 2) that it is both a tool and a result of this process (Bardin, 1986).

\section{Results}

Based on the interview analysis, professors were associated with different levels of academic inclusion as shown in the following Table 3:

\begin{tabular}{|c|c|c|c|c|c|c|c|}
\hline & $\begin{array}{l}\text { Conceptions about } \\
\text { reading }\end{array}$ & \multicolumn{2}{|c|}{ Conceptions about writing } & \multicolumn{3}{|c|}{ Academic literacies teaching approach } & \begin{tabular}{|l|} 
Level of \\
academic \\
inclusion \\
\end{tabular} \\
\hline Ana & Interactive process & \multicolumn{2}{|c|}{ Complex process } & \multicolumn{3}{|c|}{ Included in disciplinary teaching } & HIGH \\
\hline María & Interactive process & \multicolumn{2}{|c|}{ Complex process } & \multicolumn{3}{|l|}{ Remedial } & MEDIUM \\
\hline Juan & Interactive process & $\begin{array}{l}\text { Complex } \\
\text { process }\end{array}$ & Product & \multicolumn{2}{|c|}{$\begin{array}{l}\text { Included in disciplinary } \\
\text { teaching }\end{array}$} & Remedial & MEDIUM \\
\hline Pedro & \begin{tabular}{l|l} 
I & Information \\
$\mathrm{P}$ & transfer
\end{tabular} & $\begin{array}{l}C \\
P\end{array}$ & Product & \multicolumn{2}{|l|}{ IDT } & $\begin{array}{l}\mathrm{He} / \text { she is not } \\
\text { involved }\end{array}$ & LOW \\
\hline Elena & Information transfer & \multicolumn{2}{|l|}{ Product } & Remedial & \multicolumn{2}{|c|}{$\mathrm{He} /$ she is not involved } & LOW \\
\hline
\end{tabular}

Table 3: Levels of academic inclusion found in professors' discourses. (IP=Interactive process, $\mathrm{CP}=$ complex process, $\mathrm{R}=$ remedial, IDT=included in disciplinary teaching)

In Table 3, categories associated with a high level of academic inclusion appear with a darker background. As can be observed, Professor Ana presents inclusiveness in all of the analyzed dimensions and, therefore, shows a high level of academic inclusion. Meanwhile, María and Juan only have two thirds of inclusive characteristics and present a remedial approach to academic literacies teaching, which indicates a medium level of academic inclusion. Finally, Elena does not have any inclusiveness characteristics and Pedro has less than a third of these. The following details from the interviews ${ }^{4}$ provide the evidence for the characterizations of the interviewees' stated beliefs and actions summarized in Table 3 .

As the color-coding in Table 3 shows, professors who held a complex notion of the processes that readers and writers have to execute to interpret and produce knowledge (Ana, María and Juan) were able to guide students to fulfill tasks and learn from them, that is, they acknowledged that the challenges students faced during reading and writing activities were related to the disciplinary contents. Therefore, these professors could anticipate and offer the kind of help students actually needed. In addition, they could understand where students' errors and mistakes originated and could offer targeted feedback, as exemplified by the following interview fragment:

Sometimes is harder for them, as when they come across texts that are complex, that are not as simplified as others and that they are analytical, different from the ones used in secondary school, where information is not prioritized. That's something they (students) struggle with, not everyone, but younger students, I think that you 
have to guide them a lot in that, in focusing: what's the author's stance, what's the main point, so they can discern and focus on what matters (Ana)

From those who held a complex notion of reading and writing processes, only Ana showed a high level of academic inclusion: she expressed being able to empathize with students and to realize the type of help they needed to succeed in the task. This professor believed that her role was beyond transmitting knowledge or teaching (Zabalza, 2013). In her words: "I get worried about students learning from texts, because it will actually happen in real life, they will have to compare opinions" (Ana). This type of university-teaching ideas corresponds to the third level described by Biggs (2005): a professor worried about getting his/her students to learn, to reach a deep and lasting learning.

Similar to Ana, María and Juan expressed academic inclusion. However, their discourse oscillated between more and less inclusive categories in some dimensions, reason why they showed a medium level of academic inclusion. Professors' discourses revealed some complex conceptualizations about writing practices but these did not correlate with what they said to do in their classes. This may be explained by the fact that María had read some articles on academic literacies while Juan had participated in some institutional initiatives such as the ABP method. In other words, these interviewees seemed to know what they "should do" but since "knowing what to do is important only if you know why, when and how you should do it" (Biggs \& Tang, 2007, p. 18), they are in the second level of teaching.

The analysis of the interviews also indicates that those professors who had a more complex conceptualization about academic reading and writing used these practices to help students learn, and not just to evaluate them. They said to bring texts to their classes and discuss them with the students in order to facilitate not only access to disciplinary contents but also to literacy practices. In addition, they asked learners to write texts in which they had to relate two or more readings, associate the contents with their own life experiences, or solve a problem. These types of activities had the intention of fostering an epistemic use of writing where students could use it as a tool to transform knowledge (Bereiter \& Scardamalia, 1987). These characteristics appeared prominently in Ana's interview and in a lower proportion in María and Juan's. Few of them were present in Pedro's interview and none of them in Elena's.

Additionally, those professors who showed a low level of academic inclusion (Elena and Pedro) also presented a less complex conceptualization about reading and writing, seeing them as transferable skills and as something that students have to learn in previous educational levels. In addition, the category he/she is not involved (signaled with white background in Figure 1) appeared only in these two interviews. Therefore, Elena and Pedro are in the first level of teaching (Biggs, 2005), since they claimed that learning outcomes depended on students' attitudes or characteristics and that the university is not responsible for academic literacies teaching:

but you cannot spoon feed them so much. Ah, so you didn't learn to read, oh, OK, then I'll teach you. No!! All of us faced complex texts and had to re-read, because some people write in a complex way. I think that there is also something along the lines of "aw, let's help them". No!! They have to manage. (Elena)

when students get into the university environment all the fish is sold, there is little that we can do, you have to learn in elementary and secondary school. It does not matter how much effort and good will the university environment invests, it is very difficult to generate things when it is not the moment to do so ... but orthography, writing problems, syntax issues, concepts that reach the university context and you notice them and it is too late to modify them. (Pedro)

It is also worth mentioning that professors who taught first-year writing courses (Elena and María) tended to consider reading and writing as general and transferable skills. Elena considered that once people learn to read, they can read any type of material. Therefore, according to her, contextual and content elements would not affect the reading experience of a skilled person. In addition, when asked about writing, 
this interviewee stated she asked students to write about different topics since in her course she would evaluate their writing and not what they wrote about. Meanwhile, María showed a more complex notion about discursive practices. Nevertheless, when asked what could be done to teach students academic reading and writing practices, she mentioned remedial solutions, with no mention of the possibility of interweaving the teaching of academic literacy practices with disciplinary knowledge.

Finally, analysis of the interviews showed that professors who mentioned remedial solutions or did not guide students also held certain ideas about the teaching and learning of academic literacies. First, they considered that these practices were supposed to be learned once and for all and before entering higher education. Thus, there was no hope for those who did not do so at the right time given that once they arrived at the university "all the fish was sold" (Pedro). As justification why they did not hold themselves accountable for teaching these practices, some professors also embraced the idea that helping students with reading and writing was overprotective, not allowing students to mature. If we assume that "professors' knowledge and beliefs about learning, teaching, and course content are elements that determine to a large degree the ways professors teach" (Putnam \& Borko, 2000, p. 226), we can infer that our interviewees' beliefs were consistent with reticence to provide academic literacies learning support.

\section{Conclusion}

This study was based on our concern for academic inclusiveness in higher education and the assumption that disciplinary reading and writing practices are not only a content to be taught but also privileged learning tools. We explored professors' beliefs, knowledge and teaching practices as regards academic reading and writing and this helped us to distinguish three teaching profiles related to different levels of academic inclusion.

Content analysis of 5 in-depth interviews with professors who taught first-year courses in three different undergraduate programs indicates that those who acknowledged the complexity of reading and writing tended to be more inclusive, integrating these activities - and thus giving them epistemic value - with their disciplinary teaching. Second, professors who taught writing courses considered reading and writing as general skills that are not content bounded, and therefore, transferable to other contexts and spheres of knowledge. Third, less-inclusive teachers in our sample held the idea that students should already master reading and writing skills and that the university setting was not the time and place to do so. Along this line, they considered that offering reading and writing instruction implied being overprotective and not allowing students to mature, reason why they did not guide learners or propose remedial solutions such as stand-alone general writing courses.

Overall, we found that the three levels of academic inclusion that we identified were consistent with the levels of teaching as defined by Biggs (2005). The lowest level is associated with professors focused on disciplinary contents, covering the syllabus and who, when confronted with learners' failures, do not question their teaching because they consider students responsible for their own learning. Meanwhile, faculty on the highest level hold themselves accountable for student achievement by constantly reflecting on their teaching practices and the associated learning outcomes.

Although the sample was small and our results cannot be generalized, they provide insights into the complexity, locality, and situatedness of the teaching of literacy practices which is related to professors' inclusive attitudes by depicting what professors actually think and report to do. We believe that studies that are inherently local might be limited in their scope but allow in-depth characterizations that can contribute to literacy theories and research. Furthermore, we hope that the conceptual instrument that resulted from our work can be used in future studies that further analyze the relationship between faculty's teaching approaches on reading and writing and their inclusive attitudes.

\section{Notes}

1. This research was conducted in Montevideo, Uruguay, during 2013 and 2014.

2. Universities in Uruguay usually are divided into "facultades". We chose to translate this denomination 
as "departments", given that "faculty" and "department" comprise the same level in the institution where our study was conducted.

3. The analysis of the interviews was conducted in Spanish and results were translated into English for this article.

4. In-depth interviews were conducted in Spanish. Fragments were translated by the authors.

\section{References}

Altmark, S., Castrillejo, A., Debera, L., y Nalbarte, L. (2006). Elaboración de pruebas Diagnósticas al ingreso a la Facultad De Ciencias Económicas y Administración. Serie documentos de trabajo DT (06/02). Available at http://www.iesta.edu.uy/ wpcontent/uploads/2010/03/0602.pdf

Bain, K. (2007) Lo que hacen los mejores profesores universitarios. Valencia: Universitat de Valencia.

Bardin, L. (1986). Análisis de contenido (Vol. 89). Madrid: Ediciones Akal.

Behares, L. (2011) Enseñanza y producción de conocimiento. La noción de enseñanza en las políticas universitarias uruguayas. Montevideo: Departamento de publicaciones de la Universidad de la República.

Beck, I. (1996): El mejoramiento de la práctica mediante la comprensión de la lectura. In L. Resnick \& L. Klopfer, Currículum y cognición. Buenos Aires: Aique. 75-104.

Bereiter, C. \& Scardamalia, M. (1987). The psychology of written composition. Hillsdale, N.J: Lawrence Erlbaum Associates.

Biggs, J. (2005) Calidad del aprendizaje universitario. Madrid: Narcea.

Biggs J. \& Tang, C. (2007). Teaching for quality learning at the university. What the student does (3rd. ed.). London: Society for Research into Higher Education \& Open University Press.

Boado, M. (2005). Una aproximación a la deserción estudiantil universitaria en Uruguay. Montevideo: Iesalc.

Cairney, T. (1992). Enseñanza de la comprensión lectora. Madrid: Morata.

Carlino, P. (2005). Leer textos científicos y académicos en la educación superior: Obstáculos y bienvenidas a una cultura nueva. Uni-Pluri Universidad, 3(2), 1-9. Available at http://aprendeenlinea.udea.edu.co/ revistas/index.php/unip/issue/view/1171/showToc

Escribir, leer y aprender en la universidad. Buenos Aires: Fondo de Cultura Económica.
. (2009). Escribir, leer y aprender en la universidad. Una introducción a la alfabetización académica Buenos Aires: Fondo de Cultura Económica.

(2013). Alfabetización académica diez años después. Revista Mexicana de Investigación Educativa, 18(47): 355-381.

Carter, M. (2007). Ways of knowing, doing, and writing in the disciplines. College Composition and Communication, 58(3), 385-418.

Carter, M., Ferzli, M., \& Wiebe, E. N. (2007). Writing to learn by learning to write in the disciplines. Journal of Business and Technical Communication, 21(3), 278302.

Coll, C. (2001).Constructivismoyeducación:La concepción constructivista de la enseñanza-aprendizaje. In C. Coll, J. Palacios \& A. Marchesi (Comps.), Desarrollo psicológico y educación: Psicología de la educación escolar. Madrid: Alianza Editorial. 157-186.

Cooper, J. (1990). Cómo mejorar la comprensión lectora. Madrid: Visor.

Dysthe, O. (2002). Professors as mediators of academic text cultures: An interview study with advisors and Master's degree students in three disciplines in a Norwegian university. Written Communication, 19(4), 493-544.

Estienne, V., \& Carlino, P. (2004). Leer en la universidad: Enseñar y aprender una cultura nueva. Uni-pluri/ versidad 4(3), 9-17.

Flower, L. \& Hayes, J (1996) Teoría de la redacción como proceso cognitivo. In Textos en contexto. Buenos Aires: Lectura y vida, 73-110.

Goodman, K. (1986). El proceso de la lectura: consideraciones a través de las lenguas y del desarrollo. In E. Ferreiro, \& M. Gómez Palacio, Nuevas perspectivas sobre los procesos de lectura y escritura. Buenos Aires: Siglo XXI. 13-28.

Imbernón, F. (2000). Un nuevo profesorado para una nueva universidad. ¿Conciencia o presión? Revista interuniversitaria de formación del profesorado, 38: 37-46.

Ketter, J. \& Hunter, J. (2003). Creating a writer's identity on the boundaries of two communities of practice. In C. Bazerman \& D. Russell (Eds.), Writing selves. Writing societies: Research from activity perspectives. Fort Collins, CO: The WAC Clearinghouse and Mind, Culture and Activity. 307-329.

Kostouli, T. (2005). Making social meanings in contexts. In T. Kostouli (Ed.), Writing in context(s). Textual practices and learning processes in sociocultural settings (1-26). NewYork: Springer. 
124 Laura Colombo and Mónica Prior, How do faculty conceptions on reading, writing and...

Krathwohl, D. R. (1998). Methods of educational and social science research: An integrated approach. (2nd ed.). New York: Longman.

Langer, J. A., \& Applebee, A. N. (1987). How writing shapes thinking: A study of teaching and learning. Urbana, IL: National Council of Teachers of English.

Lofland, J., Snow, D., Anderson, L., \& Lofland, L. H. (2006). Analyzing social settings: A guide to qualitative observation and analysis (4th ed.). Belmont, CA: Wadsworth.

Maxwell, J. A., \& Miller, B. (2008). Categorizing and connecting strategies in qualitative data analysis. In S. Hesse-Biber \& P. Leavy (Eds.), Handbook of emergent methods. New York: The Guilford Press. 461-477.

McCarthy, L. P. (1987). A stranger in strange lands: A college student writing across the curriculum. Research in the Teaching of English, 21(3): 233-265.

Palincsar, A. \& Brown, A. (1997). La enseñanza para la lectura autorregulada. In L. Resnick, \& L. Klopfer (Ed.), Currículum y cognición (43-73). Buenos Aires: Aique.

Porlán, R. \& Rivero, A. (1998). El conocimiento de los profesores. Una propuesta formativa en el área de ciencias. Sevilla: Díada.

Prior, M. (2014). Inclusión académica universitaria. Cómo inciden las concepciones de los docentes sobre la lectura, sobre la escritura y sobre los estudiantes en su actitud inclusiva al inicio de tres carreras universitarias (unpublished Master's thesis). Instituto Universitario Centro Latinoamericano de Economía Humana, Montevideo, Uruguay.

Putnam, R. \& Borko, H. (2000) El aprendizaje del profesor: implicaciones de las nuevas perspectivas de la cognición. In B. Biddle T. Good, \& I. Goodson (Eds.), La enseñanza y los profesores I. La profesión de enseñar. Barcelona: Paidós. 219-279.

Scardamalia, M. \& Bereiter, C. (1992). Dos modelos explicativos de los procesos de composición escrita. Infancia y Aprendizaje, 58, 43-64.

Sutherland, S. (2010). Unsettling a metaphor we teach by: A hybrid essay on WAC students as "immigrants". The WAC Journal, 21, 53-67.

Zabalza, M. (2013). Ser docente es más que ser enseñante. REDU. Revista de Docencia Universitaria, 11(2): 11-13.

Recebido em: 01/03/2016

Aceito em: 20/07/2016 